\title{
Brazil's Amazonian forest carbon: the key to Southern Amazonia's significance for global climate
}

\author{
Philip M. Fearnside ${ }^{1}$
}

Received: 15 June 2015/Accepted: 8 June 2016/Published online: 11 July 2016

(c) The Author(s) 2016. This article is published with open access at Springerlink.com

\begin{abstract}
Southern Amazonia is the first region of Brazil's Amazon area to be exposed to intensive conversion to agriculture and ranching. This conversion emits greenhouse gases from the carbon stock in the biomass and soils of the previous vegetation. Quantifying these carbon stocks is the first step in quantifying the impact on global warming from this conversion. This review is limited to information on Brazilian Amazonia's carbon stocks. It indicates large amounts of carbon at risk of emission in both biomass and soils, as well as considerable uncertainty in estimates. Reducing uncertainty is a priority for research but the existence of uncertainty must not be used as an excuse for delaying measures to contain deforestation. The magnitude of carbon stocks is proportional to greenhouse gas emissions per hectare of deforestation and consequently to impact on global climate.
\end{abstract}

Keywords Carbon - Biomass - Amazonia - Soil carbon · Greenhouse gas emissions · Brazil

\section{Introduction}

Brazilian Amazonia (Fig. 1) contains a large stock of carbon that could be released to the atmosphere as greenhouse gases as a result of land use and land-use

Electronic supplementary material The online version of this article (doi:10.1007/s10113-016-1007-2) contains supplementary material, which is available to authorized users.

Philip M. Fearnside

pmfearn@inpa.gov.br

1 National Institute for Research in Amazonia (INPA), Av. André Araújo, 2936, Manaus, Amazonas CEP 69067-375, Brazil change (e.g., Fearnside et al. 2009). Carbon stock is the starting point for quantifying the climatic impacts of landuse change, both within the southern Amazonia subregion and in Brazilian Amazonia as a whole. Information specific to southern Amazonia is available for several key factors, such as the aboveground volume of the trees measured in the RADAMBRASIL surveys (Brazil, Projeto RADAMBRASIL 1973-1982), and soil carbon (e.g., Moraes et al. 1995). For various other carbon stocks, estimates depend on data from other parts of Amazonia, such as belowground biomass, dead biomass (necromass), non-tree components, and secondary forest biomass. The present review is limited to information on forest carbon stocks. These stocks are proportional to the amount of greenhouse gas emission when forests are converted to other uses (e.g., Fearnside 2016), and the emissions are therefore proportional to impact on global climate (IPCC 2013).

The importance of studies in southern Amazonia extends far beyond the limits of this subregion. Land-use changes in southern Amazonia represent processes that can be expected to expand to other parts of Amazonia if the trends seen over the past years continue (Fearnside 2008a, 2015). Southern Amazonia is the first portion of the region to face intense and large-scale deforestation and forest degradation (e.g., Egler et al. 2013) (Fig. 2); it serves therefore as a bellwether for what spread of these processes would bring to other parts of Amazonia if current trends continue. The amounts of carbon involved are uncertain, and improvement in estimates is a high priority to provide the information needed as a basis for public policies affecting the future course of development in Amazonia. Despite uncertainty, knowledge is amply sufficient to justify actions to avoid deforestation. 


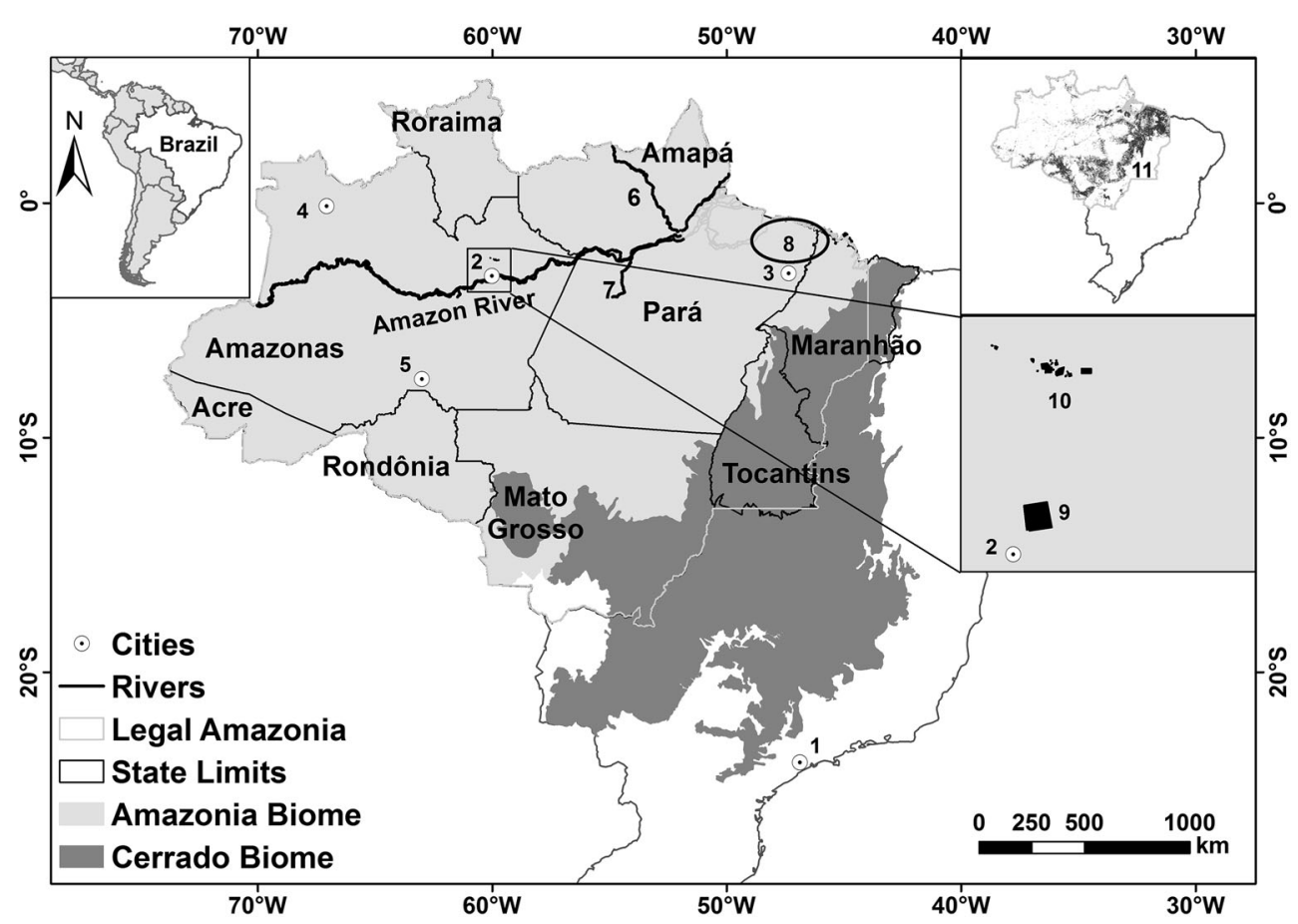

Fig. 1 Brazil and Brazilian Amazonia with locations mentioned in the text. Cities: (1) São Paulo, (2) Manaus, (3) Paragominas, (4) São Gabriel da Cachoeira; (5) Humaitá; Other: (6) Jari River, (7) CuruáUna River, (8) Zona Bragantina, (9) Ducke Reserve, (10) Biological Dynamics of Forest Fragments Project (BDFFP), (11) arc of deforestation. "Southern Amazonia" refers to the states of Rondônia, Mato Grosso, Tocantins, Maranhão, and the southern half of Pará. "Legal Amazonia" is an administrative region in Brazil

\section{Development in biomass estimation to date}

\section{Primary forest aboveground live biomass}

\section{Improving ground-based measurements}

Forest biomass is a key factor in determining the magnitude of greenhouse gas emission from tropical deforestation, as the carbon stock is directly proportional to the biomass. Improvements in biomass stock estimates continue to be made through remote sensing, through better interpretation of existing forest surveys and through on-theground studies.

Where detailed forest volume and biomass estimates have been made for closely spaced plots in a single forest type, such as the 651 -ha plots in the botanical survey of the Biological Dynamics of Forest Fragments Project (BDFFP) near Manaus, the wide variance in biomass at the level of 1-ha plots is evident. In this case, the coefficient of variation (CV) was $13.2 \%$, with mean aboveground live biomass of $356 \pm 47 \mathrm{Mg} \mathrm{ha}^{-1}$ for all trees, based on measurements for trees $\geq 10 \mathrm{~cm} \mathrm{DBH}$ (diameter at breast height: diameter at $1.3 \mathrm{~m}$ above the ground or above any encompassing all or part of nine states; $26 \%$ of Legal Amazonia is cerrado (savanna) rather than forest. Brazil also officially divides its territory into biomes, based on the predominant original vegetation. The "Amazonia biome," represents Amazonian forest, although it includes some enclaves of non-forest vegetation. The term "Brazilian Amazonia" is used when the distinction between Legal Amazonia and the Amazonia biome is not necessary

buttresses) with a $12 \%$ correction for small trees (Laurance et al. 1999). In 72 1-ha plots in the Ducke Reserve, also near Manaus, the $\mathrm{CV}$ was $12.8 \%$, with mean aboveground live biomass for trees $\geq 1 \mathrm{~cm} \mathrm{DBH}$, which allows as few as three 1-ha plots to provide an estimate with a mean value within $10 \%$ of the true mean (considering a $95 \%$ confidence interval), indicating the priority for surveys at widely spaced locations, each with only a small numbers of plots (Nascimento and Laurance 2002). Note that plots smaller than 1 ha, which are not uncommon in forest biomass studies, would have higher variance (Clark and Clark 2000).

Quantifying local variation represents a different problem from quantifying large-scale variation, which is driven by different factors. To improve large-scale assessment of aboveground biomass, the key challenge is to sample well over the vast spatial extent of the region, not to replicate mainly locally. Clearly, a large sample size is needed for this purpose.

Progress has been made in improving allometric equations for interpreting existing forest surveys, such as RADAMBRASIL. Particularly important are improvements for the forests in the "arc of deforestation," or the 
crescent-shaped strip along the southern and eastern edges of the Amazon forest biome where deforestation activity has been concentrated since 1970 (Fig. 2). Previously, the volume of wood in trees and the conversion to biomass in all of Amazonia were calculated based on measurements taken in the Manaus area in central Amazonia (e.g., Higuchi et al. 1998). However, new measurements in Southern Amazonia's arc of deforestation indicate $13.6 \%$ lower biomass there than that calculated using the parameter values from central Amazonia (Nogueira et al. 2007). Trees in the arc of deforestation have significantly lower wood density than those in central Amazonia, not only from the species composition of the forest but also with lower basic density of wood for individuals from the same species (Nogueira et al. 2007). "Basic" density is the ovendry weight divided by the wet volume, which is the most appropriate density measure for converting forest volume data to biomass (Fearnside 1997b). Part of the difference comes from lower wood density as a result of greater pore volume, which leads to higher water content: the wood in the arc of deforestation has 3-4\% higher water content as compared to wood in central Amazonia, meaning that some of what was previously being counted as biomass was actually water (Nogueira et al. 2008b). In addition, trees in the arc of deforestation are shorter for individuals of any given diameter, resulting in further overestimation of biomass (by 3.6-11.0 \%) when central Amazonian allometric equations are applied to these forests (Nogueira et al. 2008c). The importance of tree height extends to biomass estimates throughout the tropics, and incorporation of this parameter in allometric equations for forest biomass lowers estimated pantropical deforestation emissions by $13 \%$ as compared to using equations based solely on diameter (Feldpausch et al. 2011, 2012; see also: Chave et al. 2014). Wood density of tropical trees and its effect on biomass have been extensively reviewed by Chave et al. (2006).

One important factor with little data is the multiplier used to represent the biomass of tree crowns (the "biomass expansion factor," or BEF). Most existing estimates of Amazonian biomass have used values for this parameter derived from early unpublished data from Venezuela by Jean-Pierre Veillon (after Brown and Lugo 1992). However, weighing the entire aboveground portion of 267 trees in the arc of deforestation showed that the values from Venezuela overestimated this component by $6 \%$, resulting in overestimates of total aboveground live biomass by percentages ranging from 3.6 to $11.0 \%$ for forest types in the arc of deforestation (Nogueira et al. 2008a). The Venezuelan data by Veillon have been essential to many studies of Amazonian forests, but doubts concerning how the trees were measured have proved impossible to resolve: see the dispute between Clark (2002) and Phillips et al. (2002). One solution has been to remove these data from analyses of Amazonian forest dynamics (Lewis et al. 2004). Nevertheless, aside from the BEF measurement by Nogueira et al. (2008a), Veillon's estimate reported by Brown and Lugo (1992) is the only other known value for this important biomass parameter. Estimates of BEF are needed to represent the range of forest types in Amazonia. A promising possibility is use of airborne and groundbased LiDAR, which are able to measure the dimensions of branches in the crowns of standing Amazonian trees (e.g., Figueiredo 2014).

Since the RADAMBRASIL surveys do not include small trees, the biomass in these trees must be estimated by multiplying the biomass in the larger trees by a multiplier derived as the ratio between small- and large-tree biomass from sites where both have been measured. Small trees are divided into two diameter groups, each with a separate multiplier. The first multiplier represents trees with diameters between $10 \mathrm{~cm}$ and the lower limit of the forest volume surveys, such as the $31.8-\mathrm{cm}$ DBH lower limit for RADAMBRASIL data. Early estimates mistakenly omitted the 30- to 31.8-cm DBH range (see: Fearnside 1992). Aside from this problem, new data from the arc of deforestation indicate that the volume expansion factor (VEF) used for tree boles in this diameter range (e.g., from Brown and Lugo 1992) underestimates this component by $25 \%$ in the arc of deforestation (Nogueira et al. 2008a).

The second small-tree multiplier represents biomass in trees $<10 \mathrm{~cm}$ DBH. Again, a value from Venezuela (12\% of aboveground live biomass: Jordan and Uhl 1978) has been widely used in Brazilian Amazonia. Now, measurements in 72 1-ha plots located $>1000 \mathrm{~m}$ from a forest edge and spread over a $64-\mathrm{km}^{2}$ area in the Ducke Reserve, near Manaus, indicate that trees $\geq 1 \mathrm{~cm}$ and $<10 \mathrm{~cm}$ DBH represent only $6.1 \pm 1.8 \%$ of aboveground live biomass in living trees, including palms (de Castilho et al. 2006), while in 56 1-ha plots located $>300 \mathrm{~m}$ from the nearest forest-pasture edge spread over a $1000-\mathrm{km}^{2}$ area in the BDFFP reserves, also near Manaus, this percentage is $5.4 \%$ (Nascimento and Laurance 2002). In terms of total live aboveground biomass, these estimates represent a reduction of approximately $5.5 \%$ as compared to those using the values from Venezuela.

Lianas and other non-tree life forms have been omitted from a number of Amazonian biomass studies, and studies often fail to report what components are included. Standardization for non-tree components, together with trees $<10 \mathrm{~cm}$ DBH, removes almost all of the difference between aboveground live biomass estimates by Fearnside (1997a), Houghton et al. (2001) and Malhi et al. (2006) (see review in: Malhi et al. 2006, pp. 1120-1121). The importance of lianas, palms, bamboo, and other non-tree components varies greatly in different parts of the region (Online resources: Table S1). 
Fig. 2 Deforestation by 2014 (PRODES data from Brazil, INPE 2015). The curved band of heavy deforestation on the eastern and southern edges of the forest is known as the "arc of deforestation"

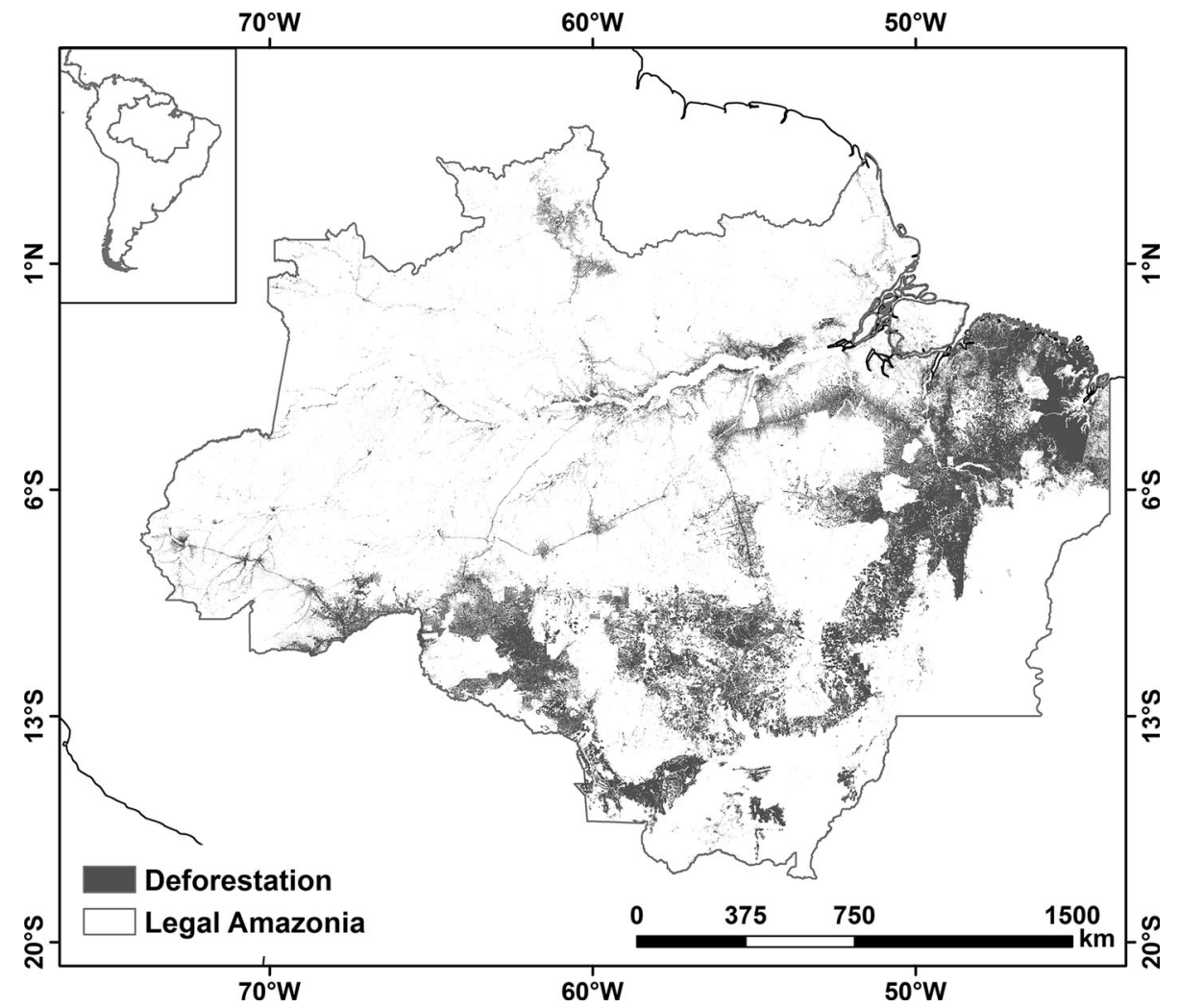

Biomass studies of Brazilian savanna woodlands (mostly cerrado), including those in Amazonia, have recently been reviewed by de Miranda et al. (2014). These authors review 26 studies at 170 sites and emphasize the contrast between the amount of available data and what has been used in global carbon computations, pointing out that the estimate by Saatchi et al. (2011) used only one study at two savanna woodland sites in Brazil. For Brazil as a whole, the review by de Miranda et al. (2014) calculates an average aboveground carbon stock of $37.4 \mathrm{Mg} \mathrm{C}^{-1}$ in savanna woodlands classified as "forestland" $(34.4 \%$ of the total savanna woodland area), and $11.5 \mathrm{Mg} \mathrm{C}^{-1}$ in those classified as "shrublands" (65.6\% of the area), giving a weighted average of $20.4 \mathrm{Mg} \mathrm{C}^{-1}$. For grasslands, aboveground biomass averaged $7.2 \mathrm{Mg} \mathrm{ha}^{-1}$ [i.e., roughly $3.6 \mathrm{Mg} \mathrm{C} \mathrm{ha}^{-1}$ ].

\section{Improving interpretation of aboveground biomass data}

Measurement of biomass density (biomass per hectare) in tropical forests from satellites is still unsatisfactory. Remote sensing has advantages over strictly ground-based estimates by providing "wall-to-wall" coverage of the entire region and by reflecting biomass of the current state of the forest, including its degradation from logging, windthrows, fires, and other disturbances. The reliability of remote sensing estimates is generally limited by the number, representativeness, and reliability (especially as related to very small plot sizes) of ground-based measurements used to calibrate the remotely sensed data.

The limitation of a miniscule number of ground locations is evident for satellite studies, as well as for studies based on interpolation between ground-based plots (Table 1). Here, "distinct locations" refer to sites reported with nonidentical geographical coordinates (those reported with identical coordinates are lumped in calculating the "plot area"). The representativeness of these samples is even less than that implied by the number of "distinct locations," since many of these are highly clustered (Fig. 3). The limited representativeness is critical in assessing an area roughly the size of Western Europe with a diverse array of forest types.

Table 1 and Fig. 3 show the contrast in terms of the amount and representativeness of ground-level information between different studies. Studies making use of the RADAMBRASIL surveys have a great advantage in terms of ground data (e.g., Nogueira et al. 2008a, 2015). This is also true of earlier interpretations of this dataset based on fewer plots and a more coarse-scale vegetation map (Fearnside 1994, 1997a). The RADAMBRASIL surveys were carried out from the late 1950s to the early 1970s using side-looking airborne radar imagery combined with 1-ha ground plots at approximately 3000 points, often reached by helicopter (de Lima 2008). The 1-:250,000 and 
Table 1 Numbers of sample plots for "primary" forests in Brazilian Amazonia used in regional biomass estimates

\begin{tabular}{|c|c|c|c|c|c|c|}
\hline Study type & References & $\begin{array}{l}\text { Plot area } \\
\geq 1 \text { ha }\end{array}$ & $\begin{array}{l}\text { Plot area } \\
<1 \text { ha }\end{array}$ & $\begin{array}{l}\text { Plot area } \\
\text { unknown }\end{array}$ & $\begin{array}{l}\text { Total distinct } \\
\text { locations }\end{array}$ & Note \\
\hline \multirow[t]{2}{*}{ Studies based on interpolation between ground-based plots } & $\begin{array}{l}\text { Houghton } \\
\text { et al. (2001) }\end{array}$ & 16 & 7 & 5 & 28 & $\mathrm{a}$ \\
\hline & $\begin{array}{l}\text { Malhi et al. } \\
(2006)\end{array}$ & 44 & 0 & 0 & 44 & \\
\hline \multirow[t]{3}{*}{$\begin{array}{l}\text { Studies based on satellite imagery calibrated } \\
\text { from ground-based plots }\end{array}$} & $\begin{array}{l}\text { Saatchi et al. } \\
\text { (2007) }\end{array}$ & 28 & 20 & 5 & 53 & $\mathrm{a}, \mathrm{b}$ \\
\hline & $\begin{array}{l}\text { Saatchi et al. } \\
\text { (2011) }\end{array}$ & 63 & 28 & 5 & 96 & $\mathrm{a}, \mathrm{b}$ \\
\hline & $\begin{array}{l}\text { Baccini et al. } \\
\text { (2012) }\end{array}$ & 0 & $?$ & 0 & $?$ & c \\
\hline \multirow{2}{*}{$\begin{array}{l}\text { Studies based on vegetation map (from airborne radar and direct } \\
\text { observation) and biomass by vegetation type from ground-based } \\
\text { plots }\end{array}$} & $\begin{array}{r}\text { Nogueira et al. } \\
(2008 \mathrm{a}, \mathrm{b}, \mathrm{c})\end{array}$ & 2879 & 0 & 0 & 2879 & \\
\hline & $\begin{array}{l}\text { Nogueira et al. } \\
\text { (2015) }\end{array}$ & 2317 & 0 & 0 & 2317 & \\
\hline
\end{tabular}

${ }^{a}$ Includes five studies with unknown sample areas (all small areas or line intersect sampling studies that are not area based)

b Includes one study with location unknown

${ }^{c}$ Baccini et al. (2012) do not report the countries or locations of their 283 0.16-ha plots distributed throughout the African, Asian, and Latin American tropics

1:1,000,000 scale RADAMBRASIL vegetation maps were developed through extensive on-the-ground and airborne observation and through visual interpretation of the highresolution radar imagery (Brazil, Projeto RADAMBRASIL 1973-1983). Use of the RADAMBRASIL surveys has been daunting to many research groups: the reports are a vast labyrinth of over 50,000 pages, written in Portuguese and historically with limited availability at any single location. However, ignoring this enormous body of work represents a loss that is not easily compensated for by applying more sophisticated remote sensing interpretation to a small set of ground-based plots.

Saatchi et al. (2007) used tree-diameter data to derive statistical relationships between the biomass at groundbased sites and a variety of spectral characteristics. The resulting relationships were then applied to the imagery from the region as a whole to estimate the biomass in each pixel. The analysis associated aboveground live biomass in the plots with a set of 19 metrics derived from satellite data for $1 \mathrm{~km}^{2}$ pixels at the plot locations. Of the 15 metrics, 9 were derived from the Moderate Resolution Imaging Spectroradiometer (MODIS): 4 for Normalized Difference Vegetation Index (NDVI), 4 for Leaf Area Index (LAI), and 1 for percent tree cover. The remaining metrics were derived from different kinds of radar: 4 metrics were derived from the Quick Scatterometer (QuikSCAT): measures of backscatter; 4 metrics were derived from Japan Earth Resources Satellite (JERS-1) data: 2 for backscatter and 2 for the coefficient of variation of the texture measure; 2 metrics were derived from Shuttle Radar Topography
Mission (SRTM) data: mean elevation and "ruggedness factor."

The Saatchi et al. (2007) study's restriction to only 53 distinct locations for ground-based information on primary forests in Brazil, with almost half having a sample area $<1$ ha or unknown, is particularly limiting. Saatchi et al. (2011) increased the ground data to 96 distinct locations in Brazilian Amazonia's primary forests. The analysis used space-borne LiDAR (Light Detection and Ranging) from the US National Aeronautics and Space Agency (NASA) Geoscience Laser Altimeter System (GLAS) on the Cloud and Land Elevation Satellite (ICESat), together with optical data from MODIS imagery and radar data from the Global Quick Scatterometer (OSCAT). Baccini et al. (2012) used spaceborne LiDAR from GLAS together with ICESat and MODIS imagery. All of these studies represent advances in interpretation of remote sensing data, but remain limited by their datasets for ground truth. Mitchard et al. (2014) contrasted the spatial results of the Saatchi et al. (2011) and Baccini et al. (2012) remote sensing studies, as well as the geographical information system (GIS) analyses derived directly from plot data by Houghton et al. (2001), Malhi et al. (2006) and their own analysis of RAINFOR (Amazon Forest Inventory Network) plots (e.g., Phillips et al. 2009). The results show major differences between all of the resulting maps, including those with largely overlapping ground-based datasets. Expanding the network of groundbased inventories is essential. The way forward will require using remote sensing data together with ground-based measurements, with progress needed in both areas. 

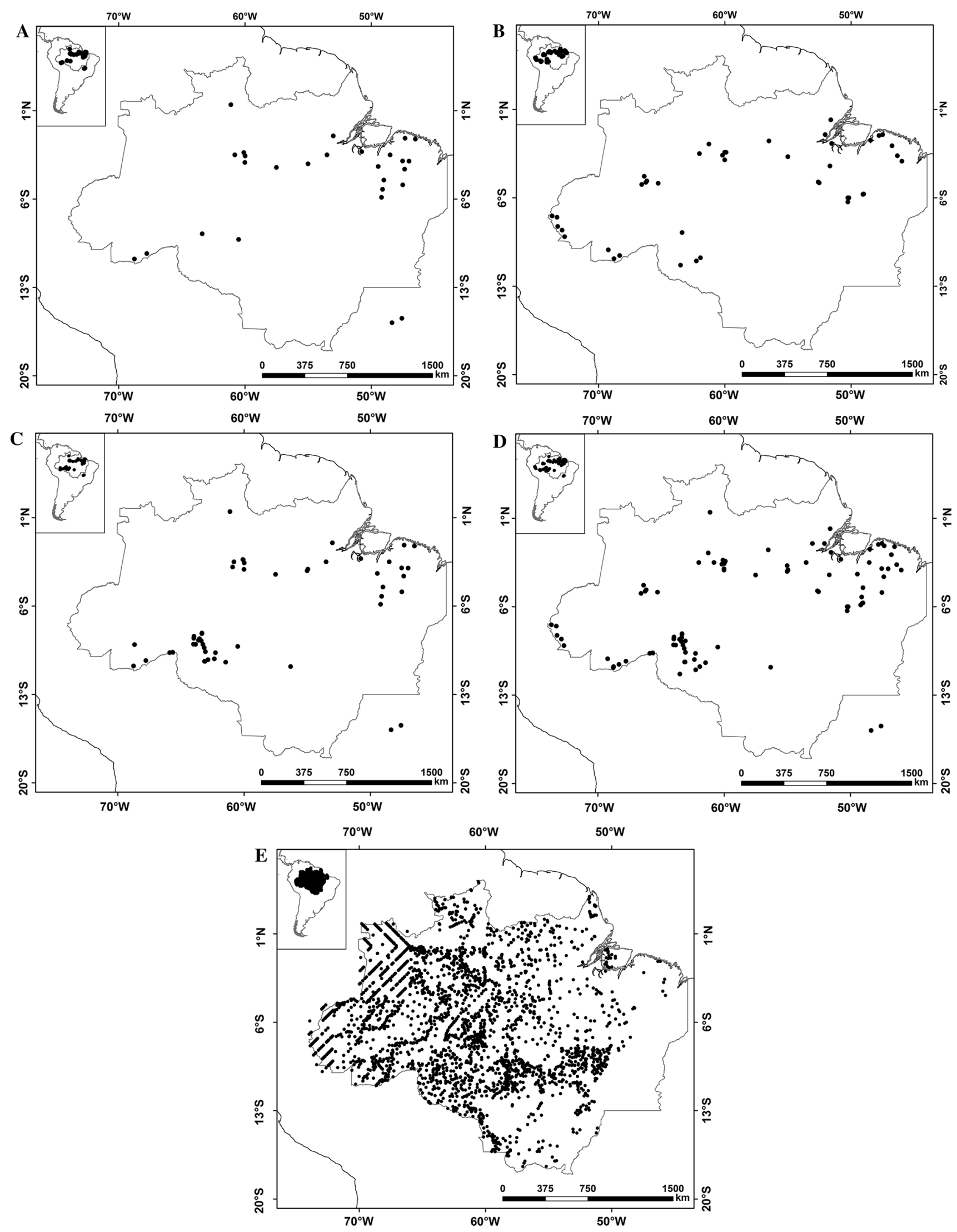
4Fig. 3 Distribution of "distinct locations" of plots used in different biomass studies (see Table 1). A = Houghton et al. (2001). $\mathrm{B}=$ Malhi et al. (2006). $\mathrm{C}=$ Saatchi et al. (2007). $\mathrm{D}=$ Saatchi et al. (2011). $\mathrm{E}=$ Nogueira et al. (2008a)

\section{Belowground biomass}

Belowground biomass (Online resources: Table S2) remains one of the areas of greatest uncertainty in biomass and emissions estimates. The response to high uncertainty of belowground estimates of simply ignoring this component by counting only aboveground biomass leads to misleading estimates. On the strength of being "uncertain," belowground biomass and change in this stock were ignored in Brazil's first national inventory under the United Nations Framework Convention on Climate Change (UNFCCC), better known as the "climate convention" (Brazil, MCT 2004, p. 146). Uncertain as estimates for this component may be, effectively using a value of zero rather than the best available estimates introduces an obvious error into overall estimates of Amazonian carbon stocks and greenhouse gas emissions from deforestation (see: Fearnside 2013a).

Belowground biomass was included in Brazil's second national inventory by assuming that Amazonian forests have $27.1 \%$ of their biomass in this component (Brazil, MCT 2010, p. 235). This is based on a measurement at a single site located in an upland (terra firme) forest (IBGE code: Db; Brazil, IBGE 2012) near Manaus (da Silva 2007). Roots $>2 \mathrm{~mm}$ in diameter were separated and weighed in 11 quadrats each measuring $10 \times 10 \mathrm{~m}$ ( 0.11 ha total); of these, 2 quadrats were excavated to $1.5 \mathrm{~m}$ depth and 9 to $1.0 \mathrm{~m}$ depth (da Silva 2007, pp. 32-34). Taproots were pulled mechanically from soil below the excavation limit, using levers tied to the stumps. Trunks, branches, and leaves from 131 trees $(\mathrm{DBH} \geq 5 \mathrm{~cm})$ in the quadrats were weighed, and the aboveground and belowground biomasses totaled for each tree.

Fearnside (1994) calculated a mean of $23.7 \%$ for this parameter based on estimates for Manaus (33.4\%), Jari $(19.8 \%)$ and Paragominas (15.2\%), which were derived from existing studies (Klinge et al. 1975; Klinge and Rodrigues 1973; Russell 1983, p. 29; Uhl et al. 1988, p. 670; see Supplementary Online Material, Table S2), complemented by information on underground boles from D.C. Nepstad (Pers. Comm.; see: Fearnside 1994, p. 111). In a global review of root biomass, Cairns et al. (1997) found tropical forests (including secondary forests) to have a mean root/shoot ratio of $0.24 \pm 0.14(n=39)$, this mean corresponding to $19.4 \%$ belowground.

Roots of an ecotone ("contact") (IBGE code: LO) between forested shade-loving campinarana (woody oligotrophic vegetation of swampy and sandy areas) and rain forest near São Gabriel da Cachoeira, Amazonas were weighed by Lima et al. (2012). This forest had an aboveground live biomass of $222.3 \pm 21.1 \mathrm{Mg} \mathrm{ha}^{-1}$, and a belowground biomass of $30.7 \pm 20 \mathrm{Mg} \mathrm{ha}^{-1}$, yielding a root:shoot ratio of 0.138 (i.e., roots represented $12.4 \%$ of the total aboveground + belowground biomass). For three types of treed savannas in Roraima, Barbosa et al. (2012) found the corresponding percentages to range from 7.5 to $16.7 \%$ for roots $\geq 2 \mathrm{~mm}$ in diameter.

The review by de Miranda et al. (2014) of savanna woodlands in Brazil as a whole calculates an average carbon stock in belowground biomass of $8.4 \mathrm{Mg} \mathrm{C} \mathrm{ha}^{-1}$ in savanna woodlands classified as "forestland" (root/shoot ratio of 0.22 , or $18.3 \%$ belowground). Belowground biomass carbon stock in savanna woodlands classified as "shrublands" is calculated at $15.8 \mathrm{Mg} \mathrm{C} \mathrm{ha}^{-1}$ (root/shoot ratio of 1.37 , or $57.9 \%$ belowground). The weighted average by area for belowground biomass carbon in "forestland" and "shrubland" savanna woodlands is 13.3 $\mathrm{Mg} \mathrm{C} \mathrm{ha}^{-1}$, and the root/shoot ratio is 0.65 , or $35.6 \%$ belowground. For grasslands, belowground biomass averaged $16.7 \mathrm{Mg} \mathrm{ha}^{-1}$ [i.e., roughly $8 \mathrm{MgC} \mathrm{ha}^{-1}$ ], and the root/shoot ratio averaged 2.3 , or $70.0 \%$ belowground. The importance of including roots is evident.

\section{Necromass (dead biomass)}

Necromass, or dead biomass, is also important to greenhouse gas emissions from deforestation. This is often omitted from estimates of deforestation emissions on the strength of the linguistic fine point of necromass not being considered as "biomass" (e.g., Brazil, MCT 2004, p. 136; note: Brazil, MCT 2010, p. 235 included a $3 \%$ adjustment for litter). The carbon contained in necromass is also released by deforestation, and each ton causes just as much climatic damage as a ton of carbon coming from live biomass. Necromass in undisturbed forests has been measured at an increasing number of sites (Online resources: Table S3). The stock of necromass varies across the Amazon region as a whole (including areas outside of Brazil), with the highest stocks being found in the northeastern corner of the region and the lowest in the northwestern corner (Chao et al. 2008, 2009). At this scale, there is a significant positive relationship between aboveground live biomass and necromass stock (Chao et al. 2009). However, an extensive survey of necromass on a northsouth transect from the Manaus area to Humaitá found no relation to aboveground live biomass, differences in necromass stocks being explained instead by soil quality and other limitations on site quality for tree growth (Martins et al. 2014). In a pantropical review, Palace et al. (2012) found that undisturbed forests had a peak of 
necromass in the middle range of aboveground live biomass values, with less necromass in both high- and lowbiomass forests.

Necromass stocks increase in forests subject to disturbances such as extreme climatic events, fire, and logging. Calculations based on observed long-term increases in tree mortality rates in the RAINFOR network of 321 permanent plots indicate that approximately $3.8 \mathrm{PgC}$ has been left in necromass in Amazonian forests since 1983, or a $30 \%$ increase in these stocks (Brienen et al. 2015, p. 346). Increases in this magnitude should be directly observable, but monitoring of necromass is rare. The RAINFOR plots are exposed to droughts, but not to logging and fire. Understory fires are increasingly common in Amazonia, resulting in substantial transfers from living to dead biomass pools (e.g., Balch et al. 2008; Barlow et al. 2003; Haugaasen et al. 2003; Vasconcelos et al. 2013). Logging has a similar effect, in addition to increasing the risk of fire (e.g., Barlow and Peres 2006; Berenguer et al. 2014; Gerwing 2002; Keller et al. 2004). A recent study in Malaysia has drawn attention to the worldwide underestimation of tropical forest emissions by ignoring necromass (Pfeifer et al. 2015).

\section{Implications of biomass uncertainties}

The large areas of annual deforestation, with most deforestation occurring in the relatively poorly studied arc of deforestation, mean that small percentage differences in biomass estimates for this part of the region translate into large amounts of greenhouse gas emission. For example, just the adjustment for lower wood density in the arc of deforestation resulted in a $23.4-24.4 \times 10^{6} \mathrm{Mg} \mathrm{CO} \mathrm{CO}^{-}$ equivalent $\mathrm{C}$ year $^{-1}$ reduction in the estimated emission for 1990 , when $13.8 \times 10^{3} \mathrm{~km}^{2}$ was deforested in the Brazilian Legal Amazon (Nogueira et al. 2007). This is approximately double the current annual emission of metropolitan São Paulo (e.g., COPPE 2005). The biomass map of Brazilian Amazonia incorporating these improvements (Nogueira et al. 2008a) provides the basis of recent emissions estimates for the region (Aguiar et al. 2012).

\section{Future prospects for measuring primary forest biomass}

Technology is advancing rapidly in areas that can provide greatly improved estimates of forest biomass. LiDAR (light detection and ranging) is able to produce accurate threedimensional representations of individual trees, including branches and irregularities, thus allowing much greater accuracy in quantifying the volume of wood present in aboveground biomass. LiDAR can measure the morphology of the crowns from airborne platforms, including pilotless aircraft (drones), while instruments recording data from a sequence of points on the ground can produce composite images of the trunks that are more accurate than manual measurements even for traditional parameters such as diameter at breast height $(\mathrm{DBH})$. Airborne LiDAR transects arranged in a top-down sampling design have produced promising results in Colombian Amazonia (Asner et al. 2012).

Radar backscatter is another avenue for improving biomass estimates (Saatchi et al. 2011; Woodhouse et al. 2012). This can be used from satellites and is advancing as a means of estimating tropical forest biomass. Space-borne LiDAR is also advancing as a biomass estimation technique (Goetz et al. 2009). However, the major spatial inconsistencies between the Saatchi and Baccini maps that both used space-borne LiDAR indicate the need for further progress in interpreting LiDAR data (Saatchi et al. 2011; Baccini et al. 2012; see: Mitchard et al. 2014).

For forest monitoring on the ground, prospects are improved by the recent discovery from the RAINFOR plot series, where only $1 \%$ of tree species account for $50 \%$ of Amazon forest biomass due to "hyperdominance" (Fauset et al. 2015). This raises the possibility of significant gains in understanding of biomass and associated biogeochemical processes by concentrating research on these species.

\section{Secondary forest}

The rate of secondary forest regrowth varies widely depending on the age of the stand, initial soil quality, and the land-use history of the site (especially use as pasture), among other factors (Online resources: Table S4). Realistic estimates of carbon uptake at a regional level are therefore highly dependent on appropriate weighting of the data on growth rates in accord with the spatial extent of secondary forests of each type. Particularly critical is the dichotomy between those derived from degraded cattle pasture versus slash-and-burn agriculture (Fearnside 1996; Fearnside and Guimarães 1996). Since secondary forests grow much more slowly in abandoned pasture than in shifting cultivation fallows, the fact that most existing studies of tropical secondary forests have been done in shifting cultivation fallows whereas the vast majority of deforested areas in Brazilian Amazonia is pasture means that calculating carbon uptake at a regional level requires care in either making separate calculations for each land-use history or properly weighting the growth rates by the proportion of each. Studies in the easily measured but highly atypical secondary forests surrounding the BDFFP reserves north of Manaus have indicated higher growth rates than in areas with typical use histories. The areas around the BDFFP reserves were abandoned prematurely as a result of 
cessation of subsidies for the ranches rather than because of the more common circumstance where a decrease in pasture productivity motivates abandonment to secondary succession (see: Fearnside 2013a).

Estimates of the extent of secondary forest in deforested portions of Brazilian Amazonia are presented in the Online Resources (Table S5). The very low values used in Brazil's second communication to the Climate Convention are unexplained (Brazil, MCT 2010, p. 242). Not all of the variation in values is the result of differences in methodology: a real reduction has occurred in the percentage of the deforested area that is in degraded pasture and secondary forest in recent years as compared to the 1980s (see: Fearnside 2013a).

Although many estimates are not explicit in defining "secondary forest," the estimates in Table S5 can all be assumed to refer to relatively recent stands, that is, since the modern age of deforestation began with the opening of the Transamazon Highway in 1970. They do not include "old" secondary forest ("capoeirões") in the Zona Bragantina of Pará and in Maranhão, many of which have been recovering since the "rubber boom" in the late nineteenth and early twentieth centuries when these areas were cleared to produce manioc and other agriculture products. These areas are considered as "deforested" in INPE's PRODES data (Brazil, INPE 2015). The area of "old" secondary forest was estimated at $71.3 \times 10^{3} \mathrm{~km}^{2}$ in 1990 (Fearnside 2000a), and most of it has since been recleared.

Brazil's first national inventory of greenhouse gas emissions claimed that secondary forests in Amazonia were absorbing $34.9 \times 10^{6} \mathrm{Mg} \mathrm{C}$ year $^{-1}$ over the 1988-1994 period (Brazil, MCT 2004, p. 147). The assumptions that underlie this high estimate have been contested (Fearnside and Laurance 2004). Recent measurements of secondary forest growth rates have confirmed slower growth than was assumed (e.g., Wandelli and Fearnside 2015). Brazil's second national inventory implies net annual accumulation of 8951.4 Gg C $\left(9.0 \times 10^{6} \mathrm{Mg} \mathrm{C}_{\text {year }}{ }^{-1}\right)$ over the 1994-2002 period (Online resources: Table S6). The average age of secondary forests in the inventory is 4 years, and the growth rates presumed are $10.1 \mathrm{MgC} \mathrm{ear}^{-1}$, a rate 2.7 times that measured for regrowth after slash-and-burn agriculture and 4.4 times higher than that measured after use as cattle pasture (Wandelli and Fearnside 2015, p. 147). Weighted by the areas of secondary forest derived from pasture $(91.4 \%)$ and agriculture $(8.6 \%)$, the inventory growth rates average 4.1 times greater than similarly weighted rates measured in Amazonian secondary forests with these two use histories under typical conditions. Even in atypically favorable conditions, growth rates do not approach those assumed in the official estimate.

Secondary forests are a significant factor in the accounts for Brazil's national emissions. The absolute value of the overestimate in the second national inventory is $6.8 \times 10^{6}$ $\mathrm{Mg} \mathrm{C}$ year $^{-1}$ (Wandelli and Fearnside 2015), which is equivalent to $8.3 \%$ of the country's fossil fuel emissions in 2005 (Brazil, MCT 2010, p. 270). This unreported land-use change emission approaches the scale of the fossil fuel emission from metropolitan São Paulo, which represents $10 \%$ of Brazil's population and presumed fossil fuel emission. São Paulo, with a population of over 20 million, is much larger than any metropolitan area in either Europe or the USA.

\section{Soil carbon}

Forest carbon is contained both in the biomass and in the soil. In the 1970s, the RADAMBRASIL project collected soil profiles at approximately 3000 points scattered (unevenly) throughout Brazilian Amazonia (Brazil, Projeto RADAMBRASIL 1973-1983). These data have been analyzed by Moraes et al. (1995), with weighting by the area of the different soil types in order to generate an estimate of the soil carbon stock in the top $1 \mathrm{~m}$ of soil under the original vegetation in the $5 \times 10^{6} \mathrm{~km}^{2}$ Brazilian Legal Amazon region. The total is $47 \mathrm{PgC}(\mathrm{PgC}=$ petagrams of carbon $=10^{15} \mathrm{gC}=$ gigatons of carbon $=$ billion $\mathrm{Mg} \mathrm{C}$ ), or an average of $94 \mathrm{Mg} \mathrm{C}^{-1}$. Uncertainty is high with the standard error equal to $24.5 \%$ of the mean (Cerri et al. 2000, p. 38). Various improvements are needed to obtain more reliable estimates of regional stocks of soil carbon (Sombroek et al. 2000). The top $20 \mathrm{~cm}$ contains 21 $\mathrm{PgC}$ (or $42 \mathrm{Mg} \mathrm{Cha}^{-1}$ ), which represents $45 \%$ of the carbon in the top meter of soil (Moraes et al. 1995).

Soil carbon is not limited to the top $1 \mathrm{~m}$ that is included in the Moraes et al. (1995) estimate. Trumbore et al. (1995) have studied soil carbon stocks to $8 \mathrm{~m}$ depth at Paragominas, Pará. The layers between 1 and $8 \mathrm{~m}$ depth there contain $155 \mathrm{Mg} \mathrm{C} \mathrm{ha}^{-1}$, or $152 \%$ of the stock at the same site in the $0-1 \mathrm{~m}$ depth range. Assuming proportionality for the remainder of the region, the deep soil contains an additional $71 \mathrm{PgC}$, making the total stock to $8 \mathrm{~m}$ $276 \mathrm{Mg} \mathrm{C} \mathrm{ha}^{-1}$, or $138 \mathrm{PgC}$ in Legal Amazonia.

The stability of the soil carbon is critical to changes when forest is cleared or undergoes other disturbances. Carbon stability affects both the total (equilibrium) carbon stock and the rate of change (i.e., the stocks in the transient states as the new equilibrium is approached). Trumbore et al. (1990, p. 411) estimated a labile (hydrolysable) soil carbon stock of $54 \mathrm{Mg} \mathrm{C} \mathrm{ha}^{-1}$ and a refractory (non-hydrolysable) soil carbon stock of $106 \mathrm{Mg} \mathrm{C}^{-1}$ in the top $60 \mathrm{~cm}$ of a typical Amazonian Ultisol from the Curuá-Una River area in Pará studied by (Sombroek 1966, p. 244). The $60-150 \mathrm{~cm}$ layer contained an additional $36 \mathrm{Mg} \mathrm{C} \mathrm{ha}^{-1}$ of labile and $40 \mathrm{Mg} \mathrm{C} \mathrm{ha}^{-1}$ of refractory carbon. The so-called refractory soil carbon belongs to a "slow-turnover" carbon pool that is 
often assumed to have no turnover at all. However, this pool does, in fact, turn over at an appreciable rate, even in the deep soil, and could therefore represent substantial carbon emissions because of the slow pool's great size in Brazilian Amazonia. Trumbore et al. (1995, p. 527) estimated a turnover time of $<25$ years for the entire soil carbon pool from 0 to $8 \mathrm{~m}$ depth under pasture.

The classic division of soil organic matter into categories as "labile" versus "recalcitrant" or "fast turnover" versus "slow turnover" has been criticized as hiding important properties of what is really a continuum (Lehmann and Kleber 2015). The soil contains a mixture of organic molecules of different sizes and with different properties relevant to their rate of oxidation, such as their association with soil minerals that can protect the organic molecules from the action of microorganisms. The molecular composition of organic matter varies with its source and is summarized in indices of organic matter "quality," reflecting the ease with which it is decomposed. Among the factors affecting the amount and activity of soil microbiota is the soil's humidity and the interactions of humidity with temperature. All of these are important areas for research in modeling carbon release from soils (Lehmann and Kleber 2015). Climate change is expected to affect both temperature and humidity, with longer and more severe droughts together with higher temperatures in Amazonia, especially southern Amazonia (Fu et al. 2013; Marengo and Espinoza 2016). Slow-turnover soil organic matter is more sensitive to release under warming than is fast turnover organic matter (Conant et al. 2008; Craine et al. 2010; Davidson and Janssens 2006). In Amazonian soils, the fast turnover organic matter is concentrated near the soil surface (de Marques et al. 2015), which is where increases in soil temperature are greatest when forests are cleared, and this would also be the layer undergoing the greatest effects of climate change. After deforestation, changes in soil organic matter depend heavily on management, with a variety of techniques resulting in enhanced organic matter retention (e.g., Fujisaki et al. 2015; Maia et al. 2009, 2010; Perrin et al. 2014). Nevertheless, the dominant land use in Brazilian Amazonia continues to be cattle pasture with minimal management (Fearnside 2005). Conversion of forest to pasture results in soil compaction, thereby increasing bulk density and the mass of soil (and carbon) that will be found in samples to any given depth; valid comparisons of soil carbon stocks in pasture versus forest therefore require comparisons on the basis of equal mass of soil rather than equal volume, and these indicate substantial losses of soil carbon under typically managed pastures (Fearnside and Barbosa 1998).

Increase in temperature through global warming could destabilize a part of the soil carbon pool. Temperature increases have a greater effect on speeding release of slow carbon pools than on labile carbon (Bellamy et al. 2005). This is because the sensitivity of reaction rates to changes in temperature (the Arrhenius function) is greater for reactants with higher activation energies, that is, for those that are less reactive or more recalcitrant (Davidson and Janssens 2006). The amounts of carbon involved make release a significant concern both for deforestation impacts (Fearnside and Barbosa 1998) and as a possible impact of global warming, contributing to a positive feedback mechanism (Davidson and Janssens 2006; Fearnside 2010; Schulze and Freibauer 2005; Townsend et al. 1992).

\section{Environmental services}

Maintenance of the carbon stocks in Amazonia avoids global warming and therefore provides a valuable environmental service. Amazon forest also recycles an enormous amount of water: annual evapotranspiration is estimated to total $8.4 \times 10^{12} \mathrm{~m}^{3}$, which is more than the Amazon River's annual discharge to the Atlantic Ocean of $6.6 \times 10^{12} \mathrm{~m}^{3}$ (Salati 2001). Approximately, $3.4 \times 10^{12}$ $\mathrm{m}^{3}$ is transported as water vapor to other regions (Fearnside 2004), about half of this making the "curve" to the south from Amazonia (Correia et al. 2006). Brazil's Southeastern region (including São Paulo) and neighboring countries are major recipients of this transport (Arraut et al. 2012). The La Plata Basin is estimated to depend on water-vapor transport from Amazonia for $70 \%$ of its annual total precipitation (van der Ent et al. 2010), and this water source is especially dominant in the Austral summer (Zemp et al. 2014). Water transport therefore represents a second important category of environmental service. A third is maintenance of biodiversity, with multiple utilitarian and non-utilitarian values (Fearnside 1999). The value of these environmental services represents a potential alternative basis for sustaining the rural population in Amazonia by maintaining the forest rather than destroying it (Fearnside $1997 \mathrm{c}, 2008 \mathrm{~b})$. The value of the forest for avoiding global warming is the closest to providing appreciable monetary flows, but the institutional mechanisms by which this goal could be achieved are still the subject of ongoing unresolved controversies (Fearnside 2012, 2013b). The magnitude of Amazonia's carbon stocks provides a powerful reason for resolving these controversies without delay.

\section{Beyond the numbers: Amazon biomass in policy decisions}

Policy decisions are made in the context of negotiations, either formal or informal. Academic discussions of biomass numbers provide one of the inputs to decisions on 
mitigating global warming and on Amazonian conservation and development priorities. Understanding the significance of the numbers requires acknowledging other components of these decisions, which potentially affect billions of dollars in monetary flows and the direction of development policy in Amazonia.

While levels of uncertainty have a place in rational choices among mitigation options (Fearnside 1995, 2000b), they also play an important role in negotiated accords that try to balance the divergent interests of the parties involved. A question such as the role of deforestation in global greenhouse gas emissions is composed of various components, such as the rate of deforestation (or amount of avoided deforestation) and the biomass of the forest being cleared. Unrealistic estimates for different components may be proposed by two sides with biases in opposite directions. Unrealistic estimates for different components may be accepted in the interests of achieving agreement, but with the final result being perceived as reasonable because the biases cancel each other out. A classic case was the estimate of $1.6 \mathrm{Pg}$ of carbon (Gt C) as the global annual emission from land-use change used in the IPCC's First Assessment Report (Watson et al. 1990, p. 11). The number was agreed in a Beijing hotel room at 3:00 am local time in a discussion between Robert Watson and Gylvan Meira Filho. Key elements were a value included in the calculation of Amazon forest biomass (Brown and Lugo 1984) that was about half the level of modern estimates and a value for the rate of Amazonian deforestation by Norman Myers (e.g., Myers 1989, 1991) that was about double the currently accepted rates for the period (see Fearnside 1990, 1994, for reviews of controversies on biomass and deforestation rates at the time). The Beijing hotel room accord has been described by both parties in public fora (personal observation). Such informal understandings hold a danger if subsequent revisions change one unrealistic component but not the component or components that offset its bias. It is not only important that the final result be realistic, but also that it be so for the right reasons (Fearnside 2001).

Although there are no comparable firsthand accounts, a similar sort of informal understanding between parties appears to apply today to the Amazon forest biomass assumed in calculating carbon benefits from avoiding deforestation. The Amazon Fund (Fundo Amazônia) was established in 2008 to receive money from other countries for purposes of avoiding deforestation and emissions in Brazil, especially the US $\$ 1$ billion offered by Norway for payment through 2015 based on progress in reducing emissions. The reductions in emissions calculated by the fund assume that net emission from Amazonian deforestation is $100 \mathrm{Mg} \mathrm{C} \mathrm{ha}^{-1}$. This value was deliberately chosen to be conservative (Brazil, MMA 2008, p. 8), and high uncertainty in biomass estimates due to lack of data for parts of Amazonia was presented as a justification for assuming the low value. In this author's opinion, adopting an explicitly conservative value may be thought of as a sort of "gentlemen's agreement," where the underestimate of per hectare emission reductions that is implicit in the fund's calculations will offset the overestimate implicit in accepting the claim that all of the decline in deforestation since the high rates that prevailed in the 1996-2005 baseline period is additional to what would have occurred in the absence of governance measures. In fact, a substantial part of the slowing of deforestation is not additional because slower deforestation is explained by lower commodity prices rather than by government measures for the period up to 2008, which represents most of the total decline through 2015 (data in: Assunção et al. 2015; see: Fearnside 2016; Fearnside et al. 2014). In 2014, Brazil reevaluated biomass estimates for calculating the emissions benefit of each hectare of avoided deforestation in Amazonia (e.g., Brazil, MMA 2014a, b). Since the revised net emission per hectare is, on average, higher than the assumed $100 \mathrm{Mg} \mathrm{C}$, the result is a shrinking of the amount of real emissions reduction obtained from the available funds.

\section{Conclusions}

1. Vegetation in southern Amazonia and throughout the Amazon region has very substantial carbon stocks that can be released as greenhouse gases upon conversion to other uses.

2. Carbon stock estimates are subject to considerable uncertainty, indicating that further research should be done but not that there should be any delay in actions to contain deforestation and reduce emissions.

3. The global warming impact of land-use conversions reflects the benefit of avoiding these conversions in favor of development based on environmental services.

Acknowledgments I thank Conselho Nacional do Desenvolvimento Científico e Tecnológico (CNPq: Proc. 304020/2010-9; 573810/20087), Fundação de Amparo à Pesquisa do Estado do Amazonas (FAPEAM: Proc. 708565) and Instituto Nacional de Pesquisas da Amazônia (INPA: PRJ15.125) for financial support. The section on soil carbon is translated and adapted from Fearnside (2010). Two reviewers contributed helpful comments.

Open Access This article is distributed under the terms of the Creative Commons Attribution 4.0 International License (http://crea tivecommons.org/licenses/by/4.0/), which permits unrestricted use, distribution, and reproduction in any medium, provided you give appropriate credit to the original author(s) and the source, provide a link to the Creative Commons license, and indicate if changes were made. 


\section{References}

Aguiar APD, Ometto JP, Nobre C, Lapola DM, Almeida C, Vieira IC, Soares JV, Alvala R, Saatchi S, Valeriano D, Castilla-Rubio JC (2012) Modeling the spatial and temporal heterogeneity of deforestation-driven carbon emissions: the INPE-EM framework applied to the Brazilian Amazon. Global Change Biol 18(11):3346-3366. doi:10.1111/j.1365-2486.2012.02782.x

Arraut JM, Nobre CA, Barbosa HM, Obregon G, Marengo JA (2012) Aerial rivers and lakes: looking at large-scale moisture transport and its relation to Amazonia and to subtropical rainfall in South America. J Clim 25:543-556. doi:10.1175/2011JCLI41891

Asner GP et al (2012) High-resolution mapping of forest carbon stocks in the Colombian Amazon. Biogeosciences 9:2683-2696. doi:10.5194/bg-9-2683-2012

Assunção J, Gandour CC, Rocha R (2015) Deforestation slowdown in the Legal Amazon: prices or policies? Environ Dev Econ 20(6):697-722. doi:10.1017/S1355770X15000078

Baccini A, Goetz SJ, Walker WS, Laporte NT, Sun M, Sulla-Menashe D, Hackler J, Beck PSA, Dubayah R, Friedl MA, Samanta S, Houghton RA (2012) Estimated carbon dioxide emissions from tropical deforestation improved by carbon-density maps. Nat Clim Change 2:182-185. doi:10.1038/nclimate1354

Balch JK, Nepstad DC, Brando PM, Curran LM, Portela O, de Carvalho Jr O, Lefebvre P (2008) Negative fire feedback in a transitional forest of southeastern Amazonia. Global Change Biol 14:1-12. doi:10.1111/j1365-2486200801655x

Barbosa RI, dos Santos JRS, da Cunha MS, Pimentel T, Fearnside PM (2012) Root biomass, root: shoot ratio and belowground carbon stocks in the open savannahs of Roraima, Brazilian Amazonia. Aust J Bot 60(5):383-395. doi:10.1071/BT11312

Barlow J, Peres CA (2006) Consequences of cryptic and recurring fire disturbances for ecosystem structure and biodiversity in Amazonian forests. In: Laurance WF, Peres CA (eds) Emerging threats to tropical forests. University of Chicago Press, Chicago, pp 225-240

Barlow J, Peres CA, Lagan BO, Haugaasen T (2003) Large tree mortality and the decline of forest biomass following Amazonian wildfires. Ecol Lett 6:6-8. doi:10.1046/j.1461-0248.2003.00394.x

Bellamy PH, Loveland PJ, Bradley RI, Lark RM, Kirk GJD (2005) Carbon losses from all soils across England and Wales 1978-2003. Nature 437:245-248. doi:10.1038/nature04038

Berenguer E, Ferreira J, Gardner TA, Aragão LEOC, de Camargo PB, Cerri CE, Durigan M, de Oliveira Junior RC, Vieira ICG, Barlow J (2014) A large-scale field assessment of carbon stocks in human-modified tropical forests. Global Change Biol 20(12):3713-3726. doi:10.1111/gcb.12627

Brazil, IBGE (Instituto Brasileiro de Geografia e Estatística) (2012) Manual técnico da vegetação brasileira: sistema fitogeográfico, inventário das formações florestais e campestres, técnicas e manejo de coleções botânicas, procedimentos para mapeamentos, $2 \mathrm{a}$ ed. IBGE, Rio de Janeiro, RJ, Brazil

Brazil, INPE (Instituto Nacional de Pesquisas Espaciais) (2015) Projeto PRODES: monitoramento da floresta amazônica brasileira por satélite. INPE, São José dos Campos, São Paulo, Brazil. http://www.obt.inpe.br/prodes/

Brazil, MCT (Ministério de Ciência e Tecnologia) (2004) Brazil's initial national communication to the United Nations Framework Convention on Climate Change. MCT, Brasília, DF, Brazil. http://www.mct.gov.br/upd_blob/0005/5142.pdf

Brazil, MCT (Ministério de Ciência e Tecnologia) (2010) Second national communication of Brazil to the United Nations Framework Convention on Climate Change. MCT, Brasília, DF, Brazil, 2 vols. http://www.mct.gov.br/upd_blob/0214/214078pdf and http://www.mct.gov.br/upd_blob/0214/214079.pdf
Brazil, MMA (Ministério do Meio Ambiente) (2008) Fundo Amazônia. MMA, Brasília, DF, Brazil. http://www.mma.gov. br/estruturas/sfb/_arquivos/fundo_amazonia_2008_95.pdf

Brazil, MMA (Ministério do Meio Ambiente) (2014a) Report of the technical assessment of the proposed forest reference emission level of Brazil submitted in 2014. FCCC/TAR/2014/BRA. http:// unfccc.int/resource/docs/2014/tar/bra01.pdf

Brazil, MMA (Ministério do Meio Ambiente), MCTI (Ministério de Ciência, Tecnologia e Inovação) (2014b) Brazil's submission of a Forest Reference Emission Level (FREL) for reducing emissions from deforestation in the Amazonia biome for REDD + results-based payments under the UNFCCC. MMA, Brasília, DF, Brazil. http://redd.mma.gov.br/images/Publicacoes/ FREL_Complete_October31_FINAL.pdf

Brazil, Projeto RADAMBRASIL (1973-1983) Levantamento de recursos naturais. Ministério das Minas e Energia, Departamento Nacional de Produção Mineral, Rio de Janeiro, Brazil, 36 vols

Brienen RJW et al (2015) Long-term decline of the Amazon carbon sink. Nature 519:344-348. doi:10.1038/nature14283

Brown S, Lugo AE (1984) Biomass of tropical forests: a new estimate based on forest volumes. Science 223:1290-1293. doi:10.1126/ science. 223.4642 .1290

Brown S, Lugo AE (1992) Aboveground biomass estimates for tropical moist forests of the Brazilian Amazon. Interciencia 17(1):8-18

Cairns MA, Brown S, Helmer EH, Baumgardner GA (1997) Root biomass allocation in the world's upland forests. Oecologia 111:1-11. doi:10.1007/s004420050201

Cerri CC, Bernoux M, Arrouays D, Feigl BJ, Piccolo MC (2000) Carbon stocks in soils of the Brazilian Amazon. In: Lal R, Kimble JM, Stewart BA (eds) Global climate change and tropical ecosystems. Advances in soil science. CRC Press, Boca Raton, pp 33-50

Chao KJ, Phillips OL, Baker TR (2008) Wood density and stocks of coarse woody debris in a northwestern Amazonian landscape. Can J For Res 38:267-276. doi:10.1139/X07-163

Chao KJ, Phillips OL, Baker TR, Peacock J, Lopez-Gonzalez G, Martínez RV, Monteagudo A, Torres-Lezama A (2009) After trees die: quantities and determinants of necromass across Amazonia. Biogeosciences 6:1615-1626. doi:10.5194/bg-61615-2009

Chave J, Muller-Landau HC, Baker TR, Easdale TA, ter Steege H, Webb CO (2006) Regional and phylogenetic variation of wood density across 2,456 neotropical tree species. Ecol Appl 16(6):2356-2367. doi:10.1890/1051-0761(2006)016[2356:RAP VOW]2.0.CO;2

Chave $\mathbf{J}$ et al (2014) Improved allometric models to estimate the aboveground biomass of tropical trees. Global Change Biol 20(10):3177-3190. doi:10.1111/gcb.12629

Clark DA (2002) Are tropical forests an important carbon sink? Reanalysis of the long-term plot data. Ecol Appl 12:3-7. doi:10. 1890/1051-0761(2002)012[0003:ATFAIC]2.0.CO;2

Clark DB, Clark DA (2000) Landscape-scale variation in forest structure and biomass in a tropical rain forest. For Ecol Manag 137:185-198. doi:10.1016/S0378-1127(99)00327-8

Conant RT, Drijber RA, Haddix ML, Parton WJ, Paul EA, Plante AF, Six J, Steinweg JM (2008) Sensitivity of organic matter decomposition to warming varies with its quality. Global Change Biol 14:868-877. doi:10.1111/j.1365-2486.2008.01541.x

COPPE (Programas de Pós-Graduação de Engenharia) (2005) Inventário de emissões de gases de efeito estufa do município de São Paulo: síntese. Prefeitura de São Paulo, Centro de Estudos Integrados sobre Meio Ambiente e Mudanças Climáticas, COPPE, Rio de Janeiro, RJ, Brazil. http://www.prefeitura.sp.gov.br/ cidade/secretarias/upload/sintesedoinventario_1250796710.pdf. Accessed 1 Jan 2016 
Correia FWS, Alvalá RCS, Manzi AO (2006) Impacto das modificações da cobertura vegetal no balanço de água na Amazônia: um estudo com modelo de circulação geral da atmosfera (MCGA). Rev Bras Meteorol 21(3a):153-167

Craine JM, Fierer N, McLauchan KK (2010) Widespread coupling between the rate and temperature sensitivity of organic matter decay. Nat Geosci 3:854-857. doi:10.1038/ngeo1009

da Silva RP (2007) Alometria, estoque e dinâmica da biomassa de florestas primárias e secundárias na região de Manaus (AM). $\mathrm{PhD}$ Thesis in tropical forest sciences Instituto Nacional de Pesquisas da Amazônia (INPA), Manaus, Amazonas, Brazil. https://wwwinpagovbr/arquivos/

Tese_Biomassa_Roseana_Silvapdf

Davidson EA, Janssens IA (2006) Temperature sensitivity of soil carbon decomposition and feedbacks to climate change. Nature 440:165-173. doi:10.1038/nature04514

de Castilho CV, Magnusson WE, de Araújo RNO, Luizão RCC, Luizão FJ, Lima AP, Higuchi N (2006) Variation in aboveground tree live biomass in a central Amazonian forest: effects of soil and topography. For Ecol Manag 234:85-96. doi:10.1016/ j.foreco.2006.06.024

de Lima MIC (2008) Projeto RADAM: uma saga amazônica. PakaTatu, Belém, Pará, Brazil

de Marques JDO, Luizão FJ, Teixeira WG, Sarrazin M, Ferreira SJF, Beldini TP, de Marques EMA (2015) Distribution of organic carbon in different soil fractions in ecosystems of central Amazonia. Rev Bras Ciên Solo 39:232-242. doi:10.1590/ 01000683 rbcs 20150142

de Miranda SC, Bustamante M, Palace M, Hagen S, Keller M, Ferreira LG (2014) Regional variations in biomass distribution in Brazilian savanna woodland. Biotropica 46(2):125-138. doi:10. 1111/btp12095

Egler M, Egler CAG, Franz B, de Araujo MSM, de Freitas MAV (2013) Indicators of deforestation in the Southern Brazilian PreAmazon. Reg Environ Change 13:263-271. doi:10.1007/s10113012-0331-4

Fauset $S$ et al (2015) Hyperdominance in Amazonian forest carbon cycling. Nat Commun 6:6857. doi:10.1038/ncomms 7857

Fearnside PM (1990) The rate and extent of deforestation in Brazilian Amazonia. Environ Conserv 17(3):213-226. doi:10.1017/ S0376892900032355

Fearnside PM (1992) Forest biomass in Brazilian Amazonia: comments on the estimate by Brown and Lugo. Interciencia 17(1):19-27

Fearnside PM (1994) Biomassa das florestas Amazônicas brasileiras In: Bandeira, RL, Reis, M, Borgonovi, MN, Cedrola, S (eds) Emissão $\times$ Seqüestro de $\mathrm{CO}_{2}$ : Uma Nova Oportunidade de Negócios para o Brasil. Companhia Vale do Rio Doce (CVRD), Rio de Janeiro, Brazil, pp 95-124

Fearnside PM (1995) Global warming response options in Brazil's forest sector: comparison of project-level costs and benefits. Biomass Bioenergy 8(5):309-322. doi:10.1016/09619534(95)00024-0

Fearnside PM (1996) Amazonian deforestation and global warming: carbon stocks in vegetation replacing Brazil's Amazon forest. For Ecol Manag 80(1-3):21-34. doi:10.1016/03781127(95)03647-4

Fearnside PM (1997a) Greenhouse gases from deforestation in Brazilian Amazonia: net committed emissions. Clim Change 35(3):321-360. doi:10.1023/A:1005336724350

Fearnside PM (1997b) Wood density for estimating forest biomass in Brazilian Amazonia. For Ecol Manag 90(1):59-89. doi:10.1016/ S0378-1127(96)03840-6

Fearnside PM (1997c) Environmental services as a strategy for sustainable development in rural Amazonia. Ecol Econ 20(1):53-70. doi:10.1016/S0921-8009(96)00066-3
Fearnside PM (1999) Biodiversity as an environmental service in Brazil's Amazonian forests: risks, value and conservation. Environ Conserv 26(4):305-321. doi:10.1017/S0376892999000429

Fearnside PM (2000a) Greenhouse gas emissions from land-use change in Brazil's Amazon region. In: Lal R, Kimble JM, Stewart BA (eds) Global climate change and tropical ecosystems. Advances in soil science. CRC Press, Boca Raton, pp 231-249

Fearnside PM (2000b) Uncertainty in land-use change and forestry sector mitigation options for global warming: plantation silviculture versus avoided deforestation. Biomass Bioenergy 18(6):457-468. doi:10.1016/S0961-9534(00)00003-9

Fearnside PM (2001) Effects of land use and forest management on the carbon cycle in the Brazilian Amazon. J Sustain For 12(1-2):79-97. doi:10.1300/J091v12n01_05

Fearnside PM (2004) A água de São Paulo e a floresta amazônica. Ciên Hoje 34(203):63-65

Fearnside PM (2005) Deforestation in Brazilian Amazonia: history, rates and consequences. Conserv Biol 19(3):680-688. doi:10. 1111/j.1523-1739.2005.00697.x

Fearnside PM (2008a) The roles and movements of actors in the deforestation of Brazilian Amazonia. Ecol Soc 13(1):23. http:// www.ecologyandsociety.org/vol13/iss1/art23/

Fearnside PM (2008b) Amazon forest maintenance as a source of environmental services. Anais Acad Bras Ciên 80(1):101-114. doi:10.1590/S0001-37652008000100006

Fearnside PM (2010) Estoque e estabilidade do carbono nos solos na Amazônia brasileira. In: Teixeira W, Kern DC, Madari BC, Lima HN, Woods WI (eds) As terras pretas de índio da Amazônia: sua caracterização e uso deste conhecimento na criação de novas áreas. Editora da Universidade Federal do Amazonas (EDUA) \& Embrapa Amazônia Ocidental, Manaus, Amazonas, Brazil, pp 259-263

Fearnside PM (2012) Brazil's Amazon forest in mitigating global warming: unresolved controversies. Clim Policy 12(1):70-81. doi:10.1080/146930622011581571

Fearnside PM (2013a) Serviços ambientais provenientes de florestas intactas, degradadas e secundárias na Amazônia brasileira. In: Peres CA, Gardner TA, Barlow J, Vieira ICG (eds) Conservação da biodiversidade em paisagens antropizadas do Brasil. Editora da Universidade Federal do Paraná, Curitiba, pp 26-57

Fearnside PM (2013b) What is at stake for Brazilian Amazonia in the climate negotiations? Clim Change 118(3):509-519. doi:10. 1007/s10584-012-0660-9

Fearnside PM (2015) Natural riches of Amazonia, deforestation and its consequences. Global Land Project News 12:22-25. http:// www.globallandproject.org/arquivos/GLPNews_Nov2015.pdf

Fearnside PM (2016) The impact of land use on carbon stocks and fluxes: implications for policy (Chapter 16). In: Nagy L, Forsberg B, Artaxo P (eds) Interactions between biosphere, atmosphere and human land use in the Amazon Basin. Springer (Ecological Studies No. 227), Heidleberg. doi:10.1007/978-3662-49902-3 16

Fearnside PM, Barbosa RI (1998) Soil carbon changes from conversion of forest to pasture in Brazilian Amazonia. For Ecol Manag 108:147-166. doi:10.1016/S0378-1127(98)00222-9

Fearnside PM, Guimarães WM (1996) Carbon uptake by secondary forests in Brazilian Amazonia. For Ecol Manag 80(1-3):35-46. doi:10.1016/0378-1127(95)03648-2

Fearnside PM, Laurance WF (2004) Tropical deforestation and greenhouse gas emissions. Ecol Appl 14(4):982-986. doi:10. 1890/03-5225

Fearnside PM, Righi CA, Graça PMLA, Keizer EWH, Cerri CC, Nogueira EM, Barbosa RI (2009) Biomass and greenhouse-gas emissions from land-use change in Brazil's Amazonian "arc of deforestation": the states of Mato Grosso and Rondônia. For Ecol Manag 258:1968-1978. doi:10.1016/j.foreco.2009.07.042 
Fearnside PM, Yanai AM, Vitel CSMN (2014) Modeling baselines for REDD projects in Amazonia: Is the carbon real? In: Gerold G, Jungkunst HF, Wantzen KM, Schönenberg, Amorim RSS, Couto EG, Madari B, Hohnwald S (eds) Interdisciplinary analysis and modeling of carbon-optimized land management strategies for Southern Amazonia. Univerditätsdrucke Göttingen, Göttingen, pp 19-28

Feldpausch TR et al (2011) Height-diameter allometry of tropical forest trees. Biogeosciences 8:1081-1106. doi:10.5194/bg-81081-2011

Feldpausch TR et al (2012) Tree height integrated into pan-tropical forest biomass estimates. Biogeosciences 9(8):3381-3403. doi:10.5194/bg-9-1-2012

Figueiredo EO (2014) Modelagem Biométrica para Árvores Individuais a partir do LiDAR em Área de Manejo de Precisão em Florestas Tropicais na Amazônia Ocidental. PhD thesis in tropical forest sciences, Instituto Nacional de Pesquisas da Amazônia (INPA), Manaus, Amazonas, Brazil

Fu R, Yin L, Li W, Arias PA, Dickinson RE, Huang L, Fernandes K, Liebmann B, Fisher R, Myneni RB (2013) Increased dry-season length over southern Amazonia in recent decades and its implication for future climate projection. Proc Natl Acad Sci USA 110:18110-18115. doi:10.1073/pnas.1302584110

Fujisaki K, Perrin A-S, Desjardins T, Bernoux M, Balbino LC, Brossard M (2015) From forest to cropland and pasture systems: a critical review of soil organic carbon stocks changes in Amazonia. Global Change Biol 21:2773-2786. doi:10.1111/gcb. 12906

Gerwing JJ (2002) Degradation of forests through logging and fire in the eastern Brazilian Amazon. For Ecol Manag 157:131-141. doi:10.1016/S0378-1127(00)00644-7

Goetz SJ, Baccini A, Laporte NT, Johns T, Walker W, Kellndorfer J, Houghton RA, Sun M (2009) Mapping and monitoring carbon stocks with satellite observations: a comparison of methods. Carbon Bal Manag 4:2. doi:10.1186/1750-0680-4-2

Haugaasen T, Barlow J, Peres CA (2003) Surface wildfires in central Amazonia: short-term impact on forest structure and carbon loss. For Ecol Manag 179:321-331. doi:10.1016/S0378-1127(02)00548-0

Higuchi N, dos Santos J, Ribeiro RJ, Minette YB (1998) Biomassa da parte aérea da vegetação da floresta tropical úmida de terra-firme da Amazônia brasileira. Acta Amazon 28(2):153-166. doi:10. 1590/1809-43921998282166

Houghton RA, Lawrence KT, Hackler JL, Brown S (2001) The spatial distribution of forest biomass in the Brazilian Amazon: a comparison of estimates. Global Change Biol 7:731-746. doi:10. 1111/j.1365-2486.2001.00426.x

IPCC (Intergovernmental Panel on Climate Change) (2013) Summary for policymakers. In: Stocker TF, Qin D, Plattner G-K, Tignor M, Allen SK, Boschung J, Nauels A, Xia Y, Bex V, Midgley PM (eds) Climate change 2013: the physical science basis. Contribution of working group I to the fifth assessment report of the intergovernmental panel on climate change. Cambridge University Press, Cambridge, pp 3-29

Jordan C, Uhl C (1978) Biomass of a tierra firme forest of the Amazon Basin. Oecol Plant 13:387-400

Keller M, Palace M, Asner GP, Pereira R, Silva JNM (2004) Coarse woody debris in undisturbed and logged forests in the eastern Brazilian Amazon. Global Change Biol 10:784-795. doi:10. 1111/j1529-8817200300770x

Klinge H, Rodrigues WA (1973) Biomass estimation in a central Amazonian rain forest. Acta Cient Venez 24:225-237

Klinge H, Rodrigues WA, Brunig E, Fittkau EJ (1975) Biomass and structure in a Central Amazonian rain forest. In: Golley F, Medina E (eds) Tropical ecological systems: trends in terrestrial and aquatic research. Springer, New York, pp 115-122. doi:10. 1007/978-3-642-88533-4_9
Laurance WF, Fearnside PM, Laurance SG, Delamonica P, Lovejoy TE, Rankin-de Merona JM, Chambers JQ, Gascon C (1999) Relationship between soils on Amazon forest biomass: a landscape-scale study. For Ecol Manag 118(1-3):127-138. doi:10.1016/S0378-1127(98)00494-0

Lehmann J, Kleber M (2015) The contentious nature of soil organic matter. Nature 528:60-68. doi:10.1038/nature16069

Lewis SL, Phillips OL, Baker TR, Lloyd J, Malhi Y, Almeida S, Higuchi N, Laurance WF, Neill D, Silva N, Terborgh J, Lezama AT, Vásquez MR, Brown S, Chave J, Kuebler C, Núñez P, Vinceti B (2004) Concerted changes in tropical forest structure and dynamics: evidence from 50 South American long term plots. Philos Trans R Soc Ser B 359:421-436. doi:10.1098/rstb. 2003.1431

Lima AJN, Suwa R, de Mello Ribeiro GHP, Kajimoto T, dos Santos J, da Silva RP, De Souza CAS, de Barros PC, Noguchi H, Ishizuka M, Higuchi N (2012) Allometric models for estimating aboveand below-ground biomass in Amazonian forests at São Gabriel da Cachoeira in the upper Rio Negro, Brazil. For Ecol Manag 277:163-172. doi:10.1016/jforeco201204028

Maia SMF, Ogle SM, Cerri CEP, Cerri CC (2009) Effect of grassland management on soil carbon sequestration in Rondônia and Mato Grosso states, Brazil. Geoderma 149:84-91. doi:10.1016/j. geoderma.2008.11.023

Maia SMF, Ogle SM, Cerri CC, Cerri CEP (2010) Changes in soil organic carbon storage under different agricultural management systems in the Southwest Amazon Region of Brazil. Soil Till Res 106:177-184. doi:10.1016/j.still.2009.12.005

Malhi Y et al (2006) The regional variation of aboveground live biomass in old-growth Amazonian forest. Global Change Biol 12:1-32. doi:10.1111/j.1365-2486.2006.01120.x

Marengo JA, Espinoza JC (2016) Extreme seasonal droughts and floods in Amazonia: causes, trends and impacts. Int J Climatol 36:1033-1050. doi:10.1002/joc.4420

Martins DL, Schietti J, Feldpausch TR, Luizão FJ, Phillips O, Andrade A, Castillho C, Laurance S, Oliveira A, Amaral I, Toledo JJ, Lugli L, Oblitas E, Purri J, Quesada CA (2014) Soilinduced impacts on forest structure drive coarse woody debris stocks across central Amazonia. Plant Ecol Divers 7(1-2):1-13. doi: $10.1080 / 175508742013879942$

Mitchard ETA et al (2014) Markedly divergent estimates of Amazon forest carbon density from ground plots and satellites. Global Ecol Biogeogr 23:935-946. doi:10.1111/geb12168

Moraes JL, Cerri CC, Melillo JM, Kicklighter D, Neil C, Skole DL, Steudler PA (1995) Soil carbon stocks of the Brazilian Amazon Basin. Soil Sci Soc Am J 59:244-247. doi:10.2136/sssaj1995. 03615995005900010038x

Myers N (1989) Deforestation rates in tropical forests and their climatic implications. Friends of the Earth, London

Myers N (1991) Tropical forests: present status and future outlook. Clim Change 19(1-2):2-32. doi:10.1007/BF00142209

Nascimento HEM, Laurance WF (2002) Total aboveground biomass in central Amazonian rainforests: a landscape-scale study. For Ecol Manag 168:311-321. doi:10.1016/S0378-1127(01)00749-6

Nogueira EM, Fearnside PM, Nelson BW, França MB (2007) Wood density in forests of Brazil's 'arc of deforestation': implications for biomass and flux of carbon from land-use change in Amazonia. For Ecol Manag 248(3):119-135. doi:10.1016/ jforeco200704047

Nogueira EM, Fearnside PM, Nelson BW (2008a) Normalization of the wood density data used in estimates of above-ground live biomass in Amazon forests. For Ecol Manag 256(5):990-996. doi:10.1016/jforeco200806001

Nogueira EM, Fearnside PM, Nelson BW, Barbosa RI, Keizer EWH (2008b) Estimates of forest biomass in the Brazilian Amazon: new allometric equations and adjustments to biomass from 
wood-volume inventories. For Ecol Manag 256(11):1853-1857. doi:10.1016/jforeco200807022

Nogueira EM, Nelson BW, Fearnside PM, França MB, de Oliveira ÁCA (2008c) Tree height in Brazil's "arc of deforestation": shorter trees in south and southwest Amazonia imply lower biomass. For Ecol Manag 255:2963-2972. doi:10.1016/ jforeco200802002

Nogueira EM, Yanai AM, Fonseca FOR, Fearnside PM (2015) Carbon stock loss from deforestation through 2013 in Brazilian Amazonia. Global Change Biol 21:1271-1292. doi:10.1111/ gcb12798

Palace M, Keller M, Hurtt G, Frolking S (2012) A review of above ground necromass in tropical forests. In: Sudarshana $\mathrm{P}$ (ed) Tropical forests. InTech, Rijeka, Croatia, pp 216-252. http:// cdnintechopencom/pdfs-wm/31970pdf

Perrin A-S, Fujisaki K, Petitjean C, Sarrazin M, Godet M, Garric B, Horth J-C, Balbino LC, Silveira Filho A, Machado PLOA, Brossard M (2014) Conversion of forest to agriculture in Amazonia with the chop-and-mulch method: does it improve the soil carbon stock? Agric Ecosyst Environ 184:101-114. doi:10.1016/j.agee.2013.11.009

Pfeifer M, Lefebvre V, Turner E, Cusack J, Khoo MS, Chey VK, Peni M, Ewers RM (2015) Deadwood biomass: an underestimated carbon stock in degraded tropical forests? Environ Res Lett 10:044019. doi:10.1088/1748-9326/10/4/044019

Phillips OL, Malhi Y, Vinceti B, Baker T, Lewis SL, Higuchi N, Laurance WF, Núñez VP, Vásquez MR, Laurance S, Ferreira LV, Stern M, Brown S, Grace J (2002) Changes in growth of tropical forests: evaluating potential biases. Ecol Appl 12:576-587. doi:10. 1890/1051-0761(2002)012[0576:CIGOTF]2.0.CO;2

Phillips OL et al (2009) Drought sensitivity of the Amazon rainforest. Science 323:1344-1347. doi:10.1126/science.1164033

Russell CE (1983) Nutrient cycling and productivity of native and plantation forests at Jari Florestal, Pará, Brazil. $\mathrm{PhD}$ thesis in ecology, University of Georgia, Athens, Georgia

Saatchi SS, Houghton RA, dos Santos Alvala RC, Soares JV, Yu Y (2007) Distribution of aboveground live biomass in the Amazon Basin. Global Change Biol 13:816-837. doi:10.1111/j.13652486.2007.01323.x

Saatchi SS, Marlier M, Chazdon RL, Clark DB, Russell AE (2011) Impact of spatial variability of tropical forest structure on radar estimation of aboveground biomass. Rem Sens Environ 115:2836-2849. doi:10.1016/j.rse.2010.07.015

Salati E (2001) Mudanças climáticas e o ciclo hidrológico na Amazônia. In: Fleischresser V (ed) Causas e dinâmica do desmatamento na Amazônia. Ministério do Meio Ambiente, Brasília, pp 153-172

Schulze ED, Freibauer A (2005) Unlocking carbon from soils. Nature 237:205-206. doi:10.1038/437205a
Sombroek WG (1966) Amazon soils: a reconnaissance of the soils of the Brazilian Amazon region. Centre for Agricultural Publications and Documentation, Wageningen, p 292

Sombroek WG, Fearnside PM, Cravo M (2000) Geographic assessment of carbon stored in Amazonian terrestrial ecosystems and their soils in particular. In: Lal R, Kimble JM, Stewart BA (eds) Global climate change and tropical ecosystems. CRC Press, Boca Raton, Florida, Advances in Soil Science, pp 375-389

Townsend AR, Vitousek PM, Holland EA (1992) Tropical soils could dominate the short-term carbon cycle feedbacks to increase global temperatures. Clim Change 22:293-303. doi:10.1007/ BF00142430

Trumbore SE, Bonani G, Wölfli W (1990) The rates of carbon cycling in several soils from AMS ${ }^{14} \mathrm{C}$ measurements of fractionated soil organic matter. In: Bouman AF (ed) Soils and the Greenhouse Effect. Wiley, New York, pp 407-414

Trumbore SE, Davidson EA, Camargo PB, Nepstad DC, Martinelli LA (1995) Below-ground cycling of carbon in forests and pastures of eastern Amazonia. Global Biogeochem Cycles 9(4):515-528. doi:10.1029/95GB02148

Uhl C, Buschbacher R, Serrão EAS (1988) Abandoned pastures in eastern Amazonia I patterns of plant succession. J Ecol 76:663-681. doi:10.2307/2260566

van der Ent RJ, Savenije HHG, Schaefli B, Steele-Dunne SC (2010) Origin and fate of atmospheric moisture over continents. Water Resour Res 46:W09525. doi:10.1029/2010WR009127

Vasconcelos SS, Fearnside PM, Graça PLMA, Nogueira EM, de Oliveira LC, Figueiredo EO (2013) Forest fires in southwestern Brazilian Amazonia: estimates of area and potential carbon emissions. For Ecol Manag 291:199-208. doi:10.1016/ jforeco201211044

Wandelli EV, Fearnside PM (2015) Secondary vegetation in central Amazonia: land-use history effects on aboveground biomass. For Ecol Manag 347:140-148. doi:10.1016/jforeco201503020

Watson RT, Rodhe H, Oeschger H, Siegenthaler U (1990) Greenhouse gases and aerosols. In: Houghton JT, Jenkins GJ, Ephraums JJ (eds) Climate change: the IPCC scientific assessment. Cambridge University Press, Cambridge, pp 1-40

Woodhouse IH, Mitchard ETA, Brolly M, Maniatis D, Ryan CM (2012) Radar backscatter is not a 'direct measure' of forest biomass. Nat Clim Change 2(8):556-557. doi:10.1038/ nclimate 1601

Zemp DC, Schleussner C-F, Barbosa HMJ, van der Ent RJ, Donges JF, Heinke J, Sampaio G, Rammig A (2014) On the importance of cascading moisture recycling in South America. Atmos Chem Phys 14:13337-13359. doi:10.5194/acp-14-13337-2014 